\title{
Three new species of Hyphessobrycon (Characiformes: Characidae) from the upper rio Araguaia basin in Brazil
}

\author{
Flávio C. T. Lima and Cristiano R. Moreira
}

Three new species of Hyphessobrycon (Characiformes: Characidae) are described from the upper rio Araguaia basin. Hyphessobrycon langeanii n. sp. is distinguished from all congeners by the presence of a well-defined, round humeral spot, a reticulate color pattern, a broad, horizontally-elongate caudal-peduncle blotch, and a relatively wide, faint midlateral dark stripe. Hyphessobrycon eilyos $\mathrm{n}$. sp. is distinguished from all congeners by the absence of humeral and caudal spots; by the presence of numerous dark chromatophores on the lateral surface of the body, intensely concentrated on the ventral region from the pelvicfin origin to the end of the caudal-fin base, dorsal, adipose, and caudal fins with carmine red pigmentation in life; and the presence of 7-11 maxillary teeth. Hyphessobrycon weitzmanorum n. sp. is distinguished from all congeners by the combination of the possession of two humeral spots and a general dark color pattern. These three new species, along with Creagrutus molinus (Characidae), Apareiodon tigrinus (Parodontidae), Aspidoras velites (Callichthyidae), an undescribed member of the Hypoptopomatinae (Loricariidae), Cnesterodon septentrionalis (Poeciliidae), and Simpsonichthys cholopteryx (Rivulidae), all of which are apparently endemic of the upper rio Araguaia, indicate that this area is a previously unrecognized area of endemism.

Três novas espécies do gênero Hyphessobrycon (Characiformes: Characidae) são descritas para a bacia do alto rio Araguaia. Hyphessobrycon langeanii n.sp. se distingue de seus congêneres pela presença de uma mancha umeral redonda e bem definida, de um padrão reticulado de colorido, de uma mancha no pedúnculo caudal horizontalmente alongada e de uma faixa longitudinal larga e difusa. Hyphessobrycon eilyos n.sp. se distingue de seus congêneres pela ausência de manchas umeral e caudal, pela presença de numerosos cromatóforos escuros nas laterais do corpo, mais concentrado na porção ventral da origem da nadadeira pélvica até o final da base da nadadeira anal, pela cor carmim nas nadadeiras dorsal, adiposa e caudal em exemplares vivos, e pela presença de 7-11 dentes maxilares. Hyphessobrycon weitzmanorum n.sp. se distingue de seus congêneres pela presença de duas manchas umerais, por um padrão geral do corpo escuro. Estas três espécies, em conjunto com Creagrutus molinus (Characidae), Apareiodon tigrinus (Parodontidae), uma espécie não descrita de Hypoptopomatinae (Loricariidae), Aspidoras velites (Callichthyidae), Cnesterodon septentrionalis (Poeciliidae) e Simpsonichthys cholopteyx (Rivulidae), todas as quais aparentemente endêmicas do alto rio Araguaia, indicam que esta área trata-se de uma área de endemismo previamente não reconhecida.

Key words: Endemism, Neotropical, Ostariophysi.

\section{Introduction}

Hyphessobrycon Durbin is a speciose genus of small characid fishes, comprising about 97 valid species (Lima et al., 2003). The genus is distributed from southern Mexico to Río de La Plata in Argentina, achieving its highest diversity in Cisandean northern South America. The systematics of Hyphessobrycon is still largely unresolved, with even the monophyletic status of the genus highly doubtful (Weitzman \& Palmer, 1997).

The examination of Hyphessobrycon samples deposited in the MZUSP yielded two undescribed species of the genus from the upper rio Araguaia. Our later collecting efforts in the same region yielded additional material of both species, along with samples of an additional new species. The three new species of Hyphessobrycon described herein constitute a heterogeneous assemblage that typifies the great intrageneric morphological diversity presently admitted within the boundaries of the genus.

\section{Material and Methods}

Counts and measurements were taken according to Fink \& Weitzman (1974: 1-2) and Menezes \& Weitzman (1990). In

Museu de Zoologia da USP, P. O. Box 42594, 04299-970 São Paulo, SP, Brazil. e-mail: fctlima@usp.br 
the descriptions, the frequency of each count is provided in parentheses after the respective count. An asterisk indicates counts of the holotype. Vertebrae, supraneurals, gill-rakers and tooth counts were taken from cleared and stained paratypes (cs), prepared according to the method of Taylor \& Van Dyke (1985). Vertebrae of the Weberian apparatus were counted as four elements and the fused PU1+U1 of the caudal region as a single element. In the material listed, the number of whole specimens of the lot comes first, followed by the number of cleared and stained specimens (when any).

Institutional abbreviations are: MCZ, Museum of Comparative Zoology, Harvard University, Cambridge; DZSRJP, Coleção de Peixes, Departamento de Zoologia, Universidade Estadual Paulista, São José do Rio Preto; MNRJ, Museu Nacional, Rio de Janeiro; MZUSP, Museu de Zoologia da Universidade de São Paulo, São Paulo; USNM, National Museum of Natural History, Smithsonian Institution, Washington D.C; and ZUEC, Coleção de Zoologia, Universidade Estadual de Campinas, Campinas.

\section{Hyphessobrycon langeanii, new species}

Figs. 1 - 4

Holotype. MZUSP 75127 (50.4 mm SL): Brazil, Mato Grosso, município de Alto Araguaia, córrego Mosquito, km 476.3 of Ferronorte railroad, $17^{\circ} 25^{\prime} 8^{\prime}$ 'S, 53 13 '60'W; C.R. Moreira \& F.C.T. Lima, 19 May 2001.

Paratypes. All localities in Brazil, Mato Grosso, município de Alto Araguaia, unless noted otherwise: MZUSP 73313 (166, 8 cs, 15.4-58.5 mm SL); MCZ 162370 (5, 29.5-31.8 mm SL); USNM 371922 (5, 26.3-31.8 mm SL); DZSJRP 5467 (5, 28.7-34.0 mm SL); ZUEC 6174 (5, 26.7-31.7 mm SL); same data as holotype. MZUSP 73322 (97, 12.8-34.8 mm SL), córrego do Sapinho, km 474.4 of Ferronorte railroad, 17²5'55'S, 5314'34'W; C.R. Moreira \& F.C.T. Lima, 19 May 2001. MZUSP 73256 (259, 8.1-34.3 mm SL); MNRJ 24780 (5, 22.5-30.4 mm SL); córrego Gordura, km 491.4 of Ferronorte railroad, $17^{\circ} 18^{\prime} 20^{\prime \prime}$ S, 5316'22'W; C.R. Moreira \& F.C.T. Lima, 15 May 2001. MZUSP 73272 (27, 14.1-37.7 mm SL), córrego Boiadeiro, km 487.08 of Ferronorte railroad, 17²0' ' 'S, 5314'53'W; C.R. Moreira \& F.C.T. Lima, 16 May 2001. MZUSP 73362 (43, 14.6-29.0 mm SL), córrego do Rancho, below Lagoa do Veado; $17^{\circ} 16^{\prime} 12^{\prime}$ 'S, 5324'52'W; C.R. Moreira \& F.C.T. Lima, 22 May 2001. MZUSP 73286 (6, 23.1-32.6mm SL), córrego Jaguatirica, km 496.46 of Ferronorte railroad, 17²1 '26”'S, 5317'49'W; C.R. Moreira \& F.C.T. Lima, 17 May 2001. MZUSP 73309 (30, 15.5-32.1 mm SL), córrego Bandeira, km 478.35 of Ferronorte railroad, $17^{\circ} 24^{\prime} 5^{\prime}$ 'S, 5313'32'W ; C.R. Moreira \& F.C.T. Lima, 18 May 2001. MZUSP 41405 (62, 13.6-29.0 mm SL), córrego do Rancho (headwaters) at swamp close to the road, c. 17²1'S, 5324'W; L.P.S. Portugal \& F. Langeani, 8 March 1989. MNRJ 20351 (2, 21.7-24.0 mm SL), córrego do Rancho, BR-364, $17^{\circ} 12^{\prime} 48^{\prime}$ 'S, 5320'17'W; F.A.G. Melo, P. A. Buckup and M.R.S. Melo, 13 Feb 2000. MZUSP 41451 (99, 15.8-32.3 mm SL), Goiás, município de Santa Rita do Araguaia, córrego Empantanado, fazenda "Heral" (Herval in a map consulted) (c. 17³2'S, 531'); L.P.S. Portugal \& F. Langeani, 7 February 1989.
Diagnosis. Hyphessobrycon langeanii can be distinguished from all congeners by the presence of a single well-defined, round to horizontally oval humeral spot, similar to the one found in species of the Astyanax bimaculatus (Linnaeus) complex (vs. humeral spot absent, double, or variously developed, never round to horizontally oval). It can also be distinguished from its congeners, except $H$. reticulatus Ellis, by the combination of a reticulate dark pigmentation pattern, a broad, horizontally-elongate caudal-peduncle blotch, a narrow dark stripe extending along the central caudal-fin rays, 5 or 6 horizontal scale rows between the dorsal-fin origin and the lateral line, 4 or 5 horizontal scale rows between the lateral line and the pelvic-fin origin, and 15-20 branched anal-fin rays. Hyphessobrycon langeanii can be distinguished from $H$. reticulatus by the possession of a conspicuous, dark round to oval humeral spot (vs. relatively faint, vertically-elongate humeral spot), a horizontally-elongate caudal-peduncle blotch (vs. vertically-elongate caudal-peduncle blotch), the midlateral dark stripe relatively wide and faint (vs. midlateral dark stripe extremely narrow and well-defined), and infraorbitals 3 and 4 co-ossified (vs. separated).

Description. Morphometric data of the holotype and paratypes are presented in Table 1. Body compressed, moderately slender, greatest body depth at pelvic-fin origin. Dorsal profile of head convex from upper lip to vertical through middle of orbit; slightly concave from latter point to tip of supraoccipital spine. Predorsal profile of body convex, dorsal-fin base posteroventrally inclined, straight to slightly convex in smaller individuals (less than $50 \mathrm{~mm} \mathrm{SL}$ ), and convex in larger specimens (see Figs. 2-3). Body profile straight to convex from end of base of dorsal fin to adipose fin; slightly concave between latter point to origin of dorsalmost procurrent caudal-fin ray. Ventral profile of head and body convex from lower lip to vertical through pectoral-fin insertion; slightly convex from latter point to pelvic-fin insertion. Ventral profile between pelvic-fin insertion and anal-fin origin straight. Body profile along anal-fin base straight to slightly convex and posterodorsally slanted. Ventral profile of caudal peduncle slightly concave.

Jaws equal, mouth terminal. Maxilla reaching middle of orbit. Premaxillary teeth in two rows (Fig. 4). Outer row with 2(2), $3(16)$, or $4 *(45)$ uni- to tricuspid teeth. Inner row with 4(8) tetrato hexacuspid teeth. Maxilla with 1(8) tri- to pentacuspid tooth. Dentary with 4(8) large, tetra- to heptacuspid teeth followed by 4(1), 5(5), 6(1), or 7(1) smaller uni- to tricuspid teeth.

Scales cycloid, with few radii. Lateral line incompletely pored, with 6(4), 7(6), $8^{*}(13), 9(18), 10(11), 11(3)$, or 12(1) perforated scales. Lateral series scales including perforated scales 30(1), 31(6), 32(17), $33 *(16), 34(10), 35(5)$, or 36(1). Horizontal scale rows between dorsal-fin origin and lateral line $5(7)$ or $6 *(49)$, not including scale of predorsal series situated just anterior to first dorsal-fin ray. Horizontal scale rows between lateral line and pelvic-fin insertion $4 *(53)$ or 5(3). Predorsal scales 10*(8), 11(33), 12(13), or 13(2). Circumpeduncular scales 12(10), 13*(26), or 14(20). Single row of 5-7 scales covering base of anterior most anal-fin rays. 


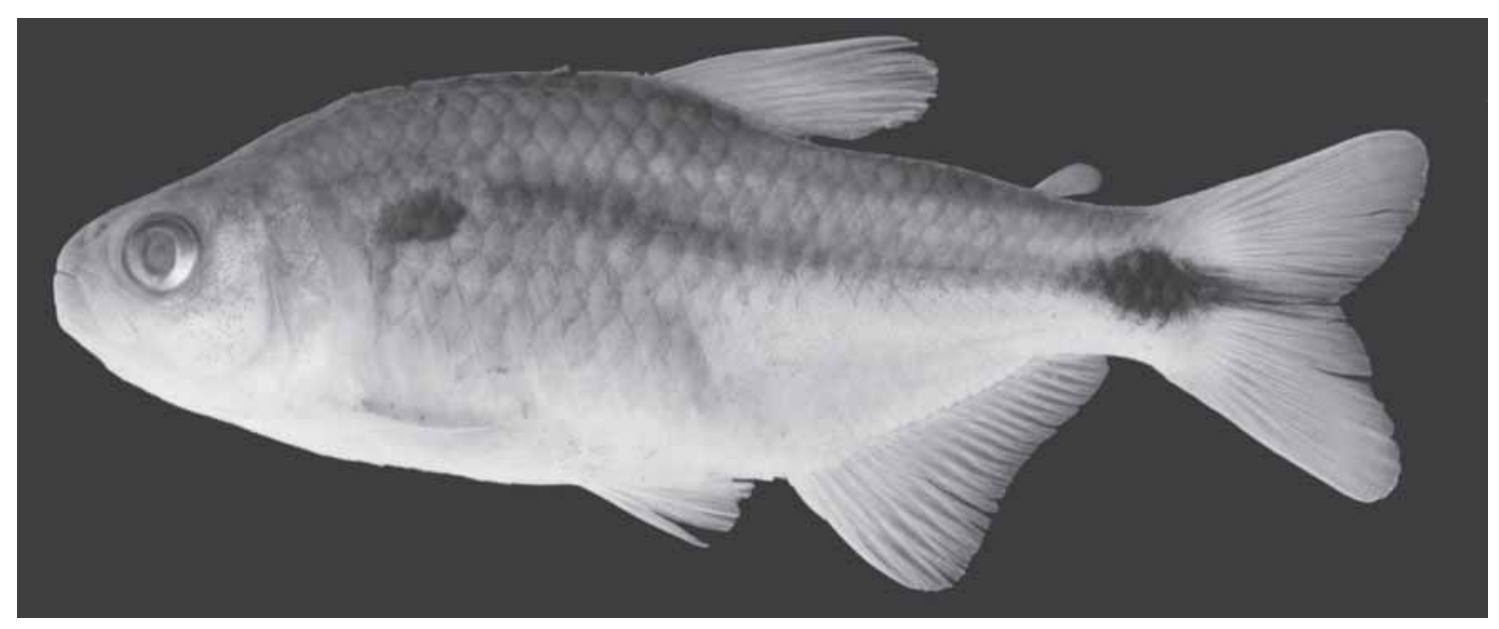

Fig. 1. Hyphessobrycon langeanii, holotype, MZUSP 75127, 50.4 mm SL, Brazil, Mato Grosso, município de Alto Araguaia, córrego Mosquito.

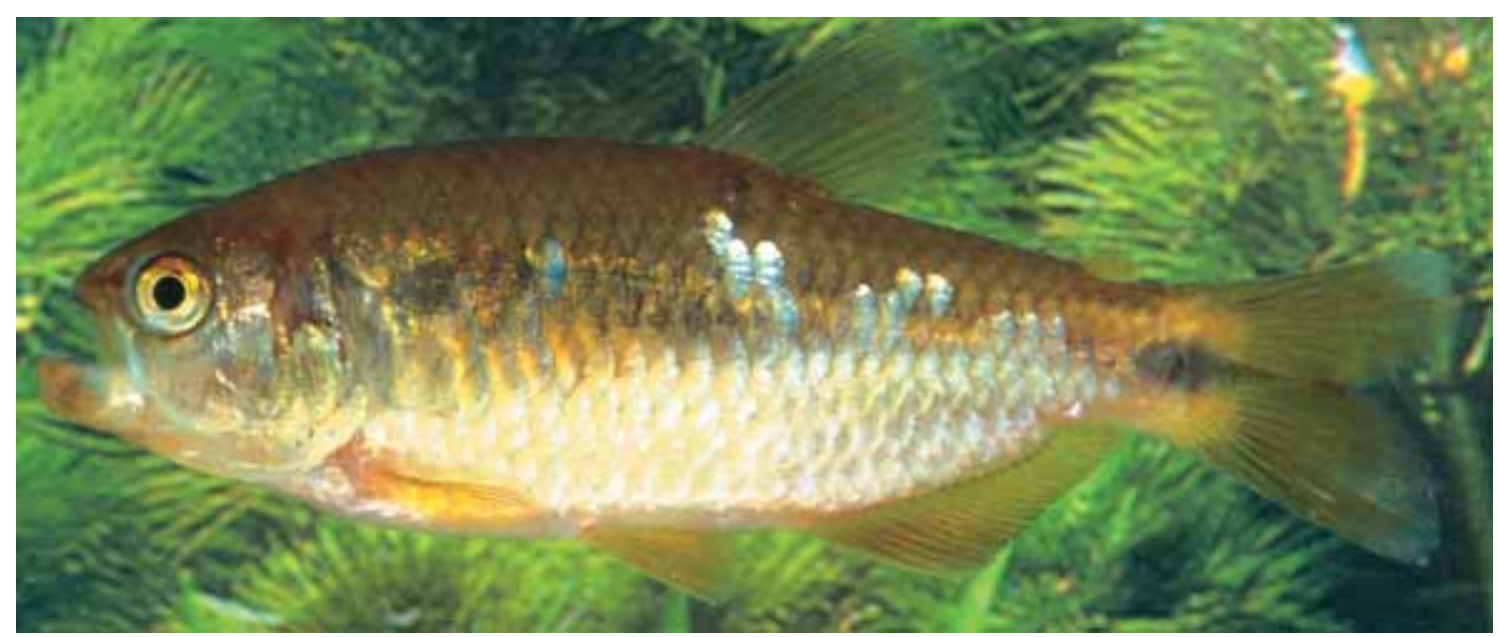

Fig. 2. Hyphessobrycon langeanii, paratype, MZUSP 73313, $58.4 \mathrm{~mm} \mathrm{SL}$, Brazil, Mato Grosso, município de Alto Araguaia, córrego Mosquito. Photographed in life.

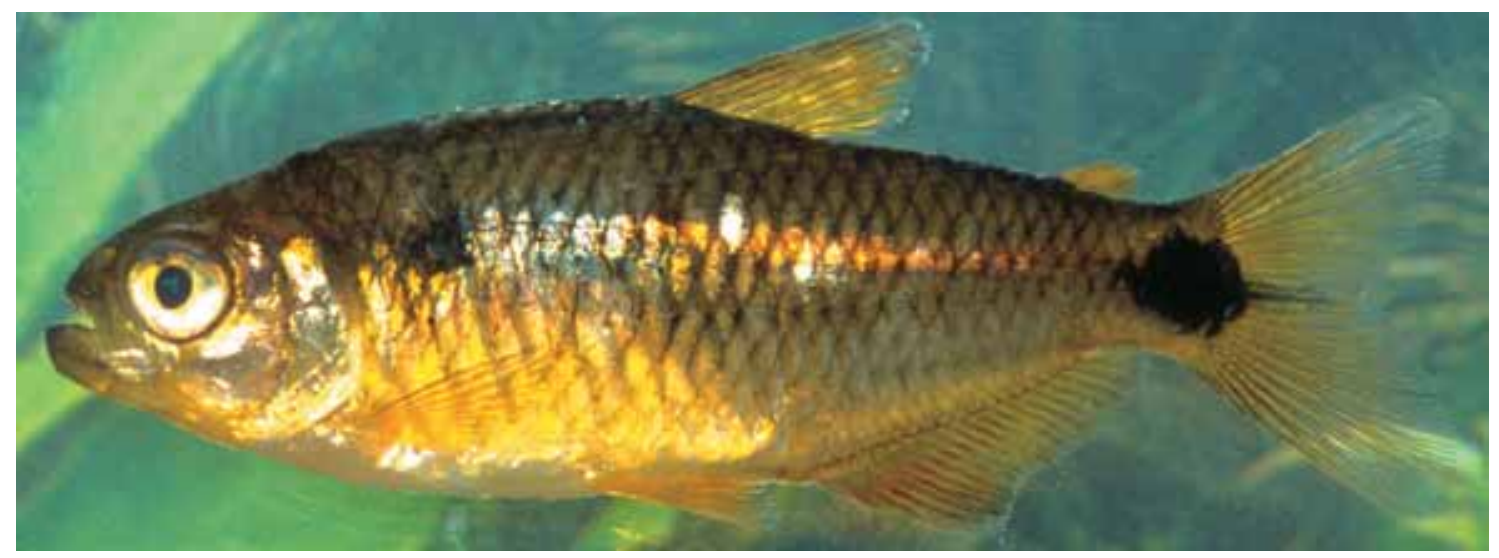

Fig. 3. Hyphessobrycon langeanii, paratype, MZUSP 73272, $37.7 \mathrm{~mm}$ SL, Brazil, Mato Grosso, município de Alto Araguaia, córrego Boiadeiro. Photographed in life. 


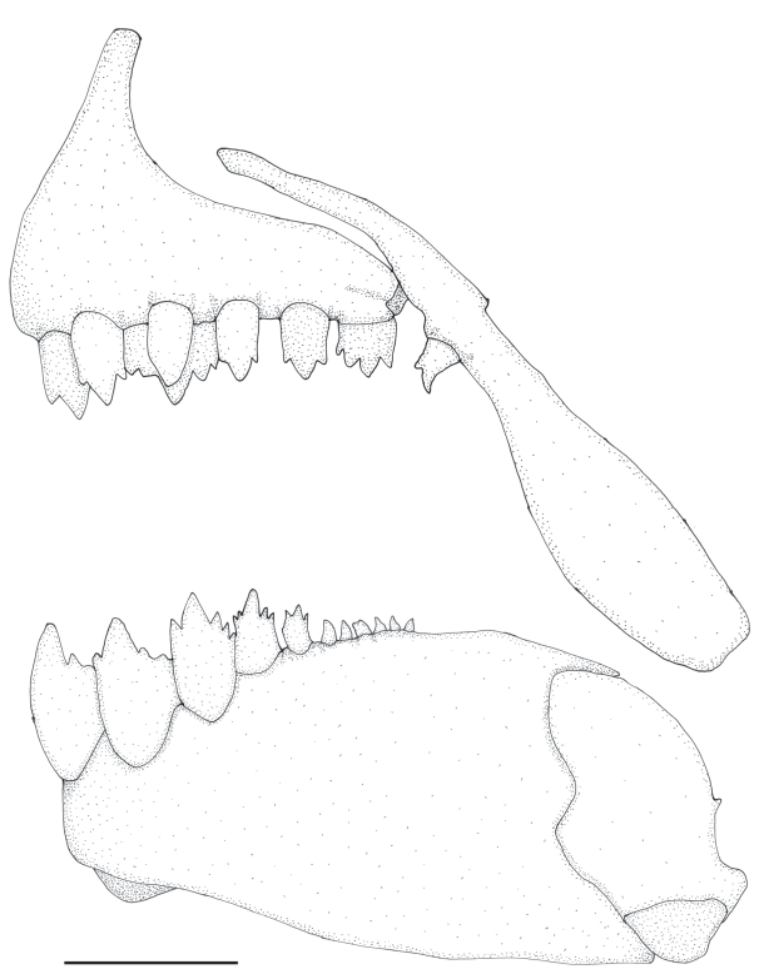

Fig. 4. Hyphessobrycon langeanii, paratype, MZUSP 73313. Upper and lower jaws, lateral view, left side. Scale bar $1 \mathrm{~mm}$.

Table 1. Morphometric data for Hyphessobrycon langeanii. Measurements based on the holotype (MZUSP 75127) and 55 paratypes (MZUSP 41405, 1 ex.; MZUSP 41451, 7 ex.; MZUSP 73256, 2 ex.; MZUSP 73272, 6 ex.; MZUSP 73309, 2 ex.; MZUSP 73313, 30 ex.; MZUSP 73322, 8 ex.).

\begin{tabular}{lrrcc}
\hline & holotype & $\mathrm{n}$ & range & mean \\
\hline Standard length (mm) & 50.4 & 56 & $26.7-58.5$ & - \\
Percents of standard length & & & & \\
Depth at dorsal-fin origin & 35.1 & 56 & $32.4-38.5$ & 35.3 \\
Snout to dorsal-fin origin & 53.8 & 56 & $52.6-58.4$ & 55.9 \\
Snout to pectoral-fin origin & 28.8 & 56 & $27.0-31.1$ & 28.9 \\
Snout to pelvic-fin origin & 48.4 & 56 & $46.0-51.3$ & 48.6 \\
Snout to anal-fin origin & 66.7 & 56 & $62.2-67.9$ & 65.5 \\
Caudal peduncle depth & 11.3 & 56 & $10.2-13.5$ & 11.7 \\
Caudal peduncle length & 14.1 & 56 & $11.1-16.7$ & 13.9 \\
Pectoral-fin length & 16.7 & 56 & $16.7-21.1$ & 18.7 \\
Pelvic-fin length & 15.5 & 56 & $12.1-19.2$ & 16.5 \\
Dorsal-fin base length & 12.9 & 56 & $10.3-14.5$ & 12.9 \\
Dorsal fin height & 24.2 & 55 & $22.5-28.2$ & 26.0 \\
Anal-fin base length & 24.4 & 56 & $21.8-28.5$ & 25.1 \\
Anal-fin lobe length & 17.1 & 54 & $14.2-20.3$ & 17.5 \\
Eye to dorsal-fin origin & 41.7 & 56 & $39.7-44.7$ & 42.3 \\
Dorsal-fin origin to caudal peduncle & 51.4 & 56 & $46.5-53.1$ & 49.9 \\
Bony head length & 28.4 & 56 & $26.8-31.1$ & 29.2 \\
Percents of head length & & & & \\
Horizontal eye diameter & 27.3 & 56 & $24.4-37.5$ & 32.5 \\
Snout length & 25.2 & 56 & $19.5-26.9$ & 23.0 \\
Least interorbital width & 35.0 & 56 & $29.9-37.3$ & 33.3 \\
Upper jaw length & 41.3 & 56 & $37.5-47.0$ & 42.5 \\
\hline
\end{tabular}

Dorsal-fin rays typically ii,9, ii,8 in one specimen. Dorsalfin origin at middle of standard length. Base of last dorsal-fin ray at vertical through anal-fin origin. First dorsal-fin pterygiophore inserting behind neural spine of 10th(2) or 11th(6) vertebra. Adipose fin present, but vestigial in one specimen. Anal-fin rays iii,15(1), 16(2), 17(11), 18*(28), 19(10), or 20(4). First anal-fin pterygiophore inserting behind hemal spine of 16 th(5) or 17 th(2) vertebra. Pectoral-fin rays i,10(14), 11*(22), 12(19), or 13(1). Tip of pectoral fin reaching vertical through pelvic-fin insertion. Pelvic-fin rays i,6*(3) or i,7(53). Caudal fin forked, lobes rounded, and similar in size. Principal caudal-fin rays $10+9(8)$. Ten (2), 11(1), 12(1), or 13(3) dorsal procurrent caudal-fin rays, and 9(1), 10(3), 11(2), or 12(1) ventral procurrent caudal-fin rays. First gill arch with 5(1), or 6(7) epibranchial, $7(5)$, or $8(3)$ ceratobranchial, 1(8) on cartilage between ceratobranchial and epibranchial, and 1(2), or 2(6) hypobranchial gill-rakers. Four (8) branchiostegal rays, 3(8) on anterior ceratohyal, and 1(8) on posterior ceratohyal. Vertebrae 31(1), 32(3), 33(3), or 34(1). Supraneurals 4(1), or 5(7).

Color in alcohol. Ground color light beige. Guanine present on opercle, infraorbitals, and sides of body. Dark chromatophores densely concentrated on dorsal surface of head, and anterior surface of lower jaw. Small, dark chromatophores present on maxilla, ventral margin of orbit, and first and second infraorbitals; remaining infraorbitals with larger and more scattered dark chromatophores. Ventral portion of head pale, almost devoid of dark chromatophores. Dorsal midline of body with dense concentration of dark chromatophores. Dark chromatophores concentrated mainly on posterior margin of scales of dorsolateral portion of body, resulting in a reticulate pattern. Ventrolateral portion of body with fewer dark chromatophores, present mainly on posterior margin of scales. Humeral spot well-defined, black, and round to horizontally oval. Thin vertical lines extend posterodorsally and anteroventrally from humeral spot. Narrow dark, midlateral stripe running from immediately posterior to humeral spot to caudal-peduncle blotch. Caudal-peduncle blotch large, welldefined, and horizontally-elongate, its depth ranging from half to two-thirds of caudal peduncle depth (compare Figs.13 ; notice that Fig. 2 is slightly overexposed and consequently caudal peduncle blotch is not so conspicuous). Narrow, dark stripe on three middle caudal-fin rays running from caudalpeduncle blotch to distal margin of fin. Remaining portions of caudal fin with scattered dark chromatophores. Dorsal and anal fins hyaline, with small dark chromatophores scattered on interradial fin membranes; chromatophores more concentrated on distal portion of five anterior dorsal-fin rays, and distal margin of anal fin. Pectoral and pelvic fins almost hyaline, with few dark chromatophores. Adipose fin dusky.

Color in life. Description based on three photographed specimens (MZUSP 73272, 2 ex, 31.8-37.7 mm SL; MZUSP 73313, 1 ex, 58.5 mm SL; Figs.2-3). Ground color beige. Sides of head, and body golden. All fins, except pelvic fin, yellow. Pelvic fin and anterior portion of anal fin orange. 


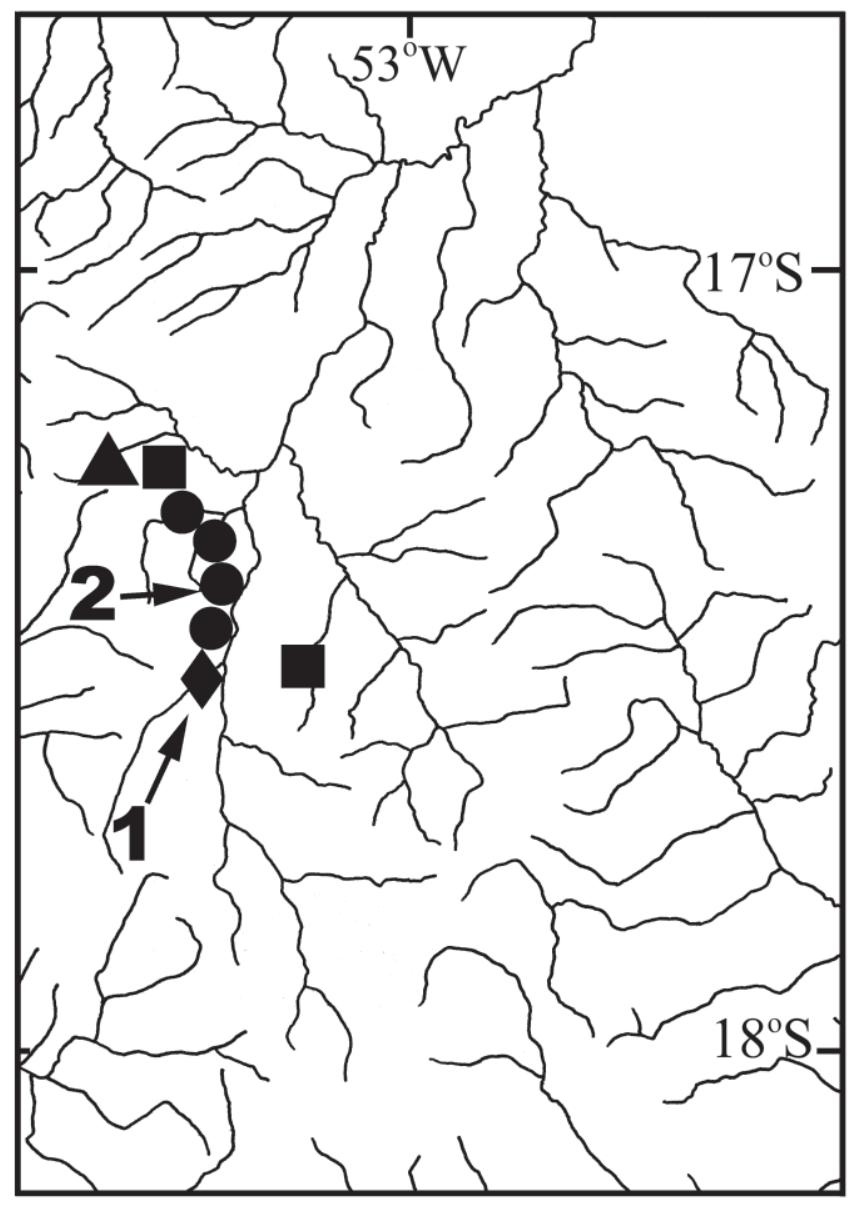

Fig. 5. Upper rio Araguaia basin, showing sites of occurrence of Hyphessobrycon langeanii, $H$. eilyos, and $H$. weitzmanorum (diamonds), $H$. langeanii and $H$. weitzmanorum (dots), H. langeanii and H. eilyos (triangle), or H. langeanii (squares). 1. Ribeirão do Sapo, type locality of $H$. eilyos. 2. Córrego Mosquito, type locality of $H$. langeanii and $H$. weitzmanorum.

Geographic distribution. Hyphessobrycon langeanii is known from several streams in the upper rio Araguaia basin, states of Mato Grosso and Goiás, Brazil (Fig. 5).

Ecological notes. We observed Hyphessobrycon langeanii in schools, generally at midwater, sometimes associated with an unidentified Astyanax species. Habitats occupied by the species ranged from relatively large, deep, clearwater streams partially covered with aquatic vegetation (i.e., ribeirão do Sapo, córrego Gordura) to shallow, small streams with flooded areas (i.e., córrego Mosquito). Hyphessobrycon langeanii was collected syntopically with $H$. weitzmanorum at córrego Gordura, córrego Boiadeiro, córrego do Sapinho, and córrego do Mosquito, with $H$. eilyos at córrego do Rancho, and with both species at the ribeirão do Sapo. The occurrence of Hyphessobrycon langeanii in a broad number of sites, even in highly degraded, silted streams such as córrego Bandeira, might indicate a tolerance of broader ecological conditions by Hyphessobrycon langeanii than is the case of its congeners in the upper rio Araguaia (see "Ecological notes" of H. eilyos and $H$. weitzmanorum, below).

Stomach contents of two cleared and stained individuals yielded ants, a beetle, chironomid larvae, unidentified Microcrustacea, diatoms and filamentous algae.

Etymology. The new species is named after our colleague Francisco Langeani, who first collected the new species.

\section{Hyphessobrycon eilyos, new species}

Figs. 6-7

Holotype. MZUSP 75126 (22.3 mm SL): Brazil, Mato Grosso, município de Alto Araguaia, ribeirão do Sapo, km 464.04 of Ferronorte railroad, 17³1'11'S, 5315'33'W; C. R. Moreira \& F.C.T. Lima, 21 May 2001.

Paratypes. All localities in Brazil, Mato Grosso, município de Alto Araguaia: MZUSP 73344 (11, 15.0-23.3 mm SL), same data as holotype. MZUSP 73363 (1, $22.1 \mathrm{~mm} \mathrm{SL),} \mathrm{córrego} \mathrm{do}$ Rancho, below lagoa do Veado, $17^{\circ} 16^{\prime} 12^{\prime}$ 'S, 5324'52'W; C.R. Moreira \& F.C.T. Lima, 22 May 2001. MZUSP 41406 (179, 5 cs, 14.6-24.7 mm SL); MCZ 162371 (5, 20.4-23.6 mm SL); USNM 371923 (5, 19.5-23.1 mm SL); MNRJ 24781 (5, 21.6-22.1 mm SL), córrego do Rancho (headwaters), swamp near the road, approx. $17^{\circ} 16^{\prime}$ S, 5324'W; L.P.S. Portugal \& F. Langeani, 8 March 1989.

Diagnosis. Hyphessobrycon eilyos is distinguished from its congeners by the absence of humeral and caudal spots; by the presence of numerous dark chromatophores on the lateral surface of the body, with the chromatophores intensely concentrated on the ventral region from the pelvic-fin origin to the end of the caudal-fin base; dorsal, adipose, and caudal fins with carmine red pigmentation in life; the presence of 7 11 maxillary teeth; 6 or 7 horizontal scale rows between the dorsal-fin origin and the lateral line; and 15 to 19 branched anal-fin rays. Detailed comparisons between $H$. eilyos and congeners sharing a general dark color pattern are presented in the "Discussion", below.

Description. Morphometric data of the holotype and paratypes are presented in Table 2. Body compressed, moderately deep, greatest body depth immediately anterior to dorsal-fin origin. Dorsal profile of head slightly convex from upper lip to vertical through middle of the orbit; straight to slightly concave from latter point to tip of supraoccipital spine. Predorsal profile of body convex, dorsal-fin base straight to slightly convex, posteroventrally inclined. Body profile straight to convex from end of dorsal-fin base to adipose fin; slightly concave between latter point and origin of dorsal most procurrent caudal-fin ray. Ventral profile of head and body convex from lower lip to pelvic-fin origin. Body profile 
straight from pelvic-fin insertion to anal-fin origin. Body profile along anal-fin base posterodorsally slanted and slightly concave to slightly convex. Ventral profile of caudal peduncle slightly concave.

Jaws unequal, mouth terminal, anteroventral end of dentary protruding slightly. Maxilla extends posteriorly to under middle of orbit. Premaxillary teeth in two rows (Fig. 7). Outer row with 3(7) uni- to tricuspid teeth. Inner row with 6(7) tri- to pentacuspid teeth. Maxilla with 7(2), 8(3), 9(1), or 11(1), uni- to tricuspid teeth. Dentary with 4(3), 5(3), or 6(1) large tricuspid teeth followed by $9(1), 11(3), 12(2)$, or 14(1) smaller uni- to tricuspid teeth.

Scales cycloid, with few radii. Lateral line incompletely pored, with 3(1), 4(7), 5(18), $6 *(13)$, or 8(1) perforated scales. Lateral series scales including perforated scales 28(1), 29(2), $30 *(10), 31(5), 32(1)$, or 33(1). Horizontal scale rows between dorsal-fin origin and lateral line $6 *(26)$ or 7(16), not including scale of predorsal series situated just anterior to first dorsalfin ray. Horizontal scale rows between lateral line and pelvicfin origin $4 *(43)$ or 5(3). Predorsal scales 9(1), 10*(8), 11(7), 12(4), or 13(1). Circumpeduncular scales 11(1), 12(4), 13(7), or 15(1). Single row of 5-6 scales covering basis of anteriormost anal-fin rays.

Dorsal-fin rays ii,8(3), or ii, $9 *(61)$. Dorsal-fin origin at middle of standard length. Base of last dorsal-fin ray at vertical through just before anal-fin origin. First dorsal-fin pterygiophore inserting behind neural spine of $9 \operatorname{th}(7)$ vertebra. Adipose fin typically present, but reduced in some specimens, and absent in 52 of 215 specimens examined. Unbranched anal-fin rays iii*(52) or iv(12). Branched anal fin rays 15(1), $16(4), 17 *(28), 18(23)$, or 19(8). First anal-fin pterygiophore inserting behind hemal spine of 15th(1), or 16th(6) vertebra. Pectoral-fin rays i,7(1), 9(4), 10(27), 11*(29), or 12(3). Specimens up to $14.9 \mathrm{~mm}$ SL retaining larval pectoral fin anatomy. Tip of pectoral fin reaching vertical through pelvic-fin origin. Pelvicfin rays i,5(7), $6 *(56)$, or 9(1). Tip of pelvic fin reaching origin of anal fin. Caudal fin forked, upper and lower lobes rounded, and similar in size. Principal caudal-fin rays 10+9(4). Eight (1), 10(1), or 12(2) dorsal procurrent caudal-fin rays, and 9(1), 10(2), or 11(1) ventral procurrent caudal-fin rays. First gill arch with 6(7) epibranchial; 1(7) on cartilage between epibranchial and ceratobranchial, 10(7) ceratobranchial, and 2(7) hypobranchial gill-rakers. Four (7) branchiostegal rays, 3(7) on anterior ceratohyal, and 1(7) on posterior ceratohyal Vertebrae 32(4), 33(2), or 34(1). Supraneurals 4(5), or 5(2).

Color in alcohol. Ground color cream, tanner in specimens stored for long time in ethanol. Guanine present on opercle and infraorbitals. Dark chromatophores densely concentrated on dorsal surface of head, and anterior surface of lower jaw. Dark chromatophores scattered on remaining portions of head. Dorsal midline with dense concentration of small dark chromatophores. Dorso and ventrolateral portions of body with dense concentration of dark chromatophores, uniformly distributed. Humeral spot absent (apparent humeral spot in Fig. 6 is actually a result of the reduction of the musculature in that portion of the body wall). Dense concentration of deep-lying dark chromatophores along ventral midline, more concentrated from pelvic-fin insertion to posterior portion of anal-fin base. Chromatophores on caudal-fin base absent, resulting in a light area. Caudal fin with dark chromatophores concentrated on middle rays and distal margin. Dorsal fin with concentration of dark chromatophores along distal margin. Anal fin with heavy concentration of dark chromatophores, mainly on interradial fin membrane. Pectoral, pelvic, and adipose fins with dense concentration of dark chromatophores.

Color in life. Description based on photograph of the holotype (MZUSP 75126). Ground color dark gray. Sides of head, and body silvery. Dorsal and adipose fins bright red. Caudal fin bright red, except for distal portion of caudal-fin lobes.

Geographic distribution. Hyphessobrycon eilyos is known from córrego do Rancho and ribeirão do Sapo, both tributaries of the upper rio Araguaia basin in the state of Mato Grosso, Brazil (Fig. 5).

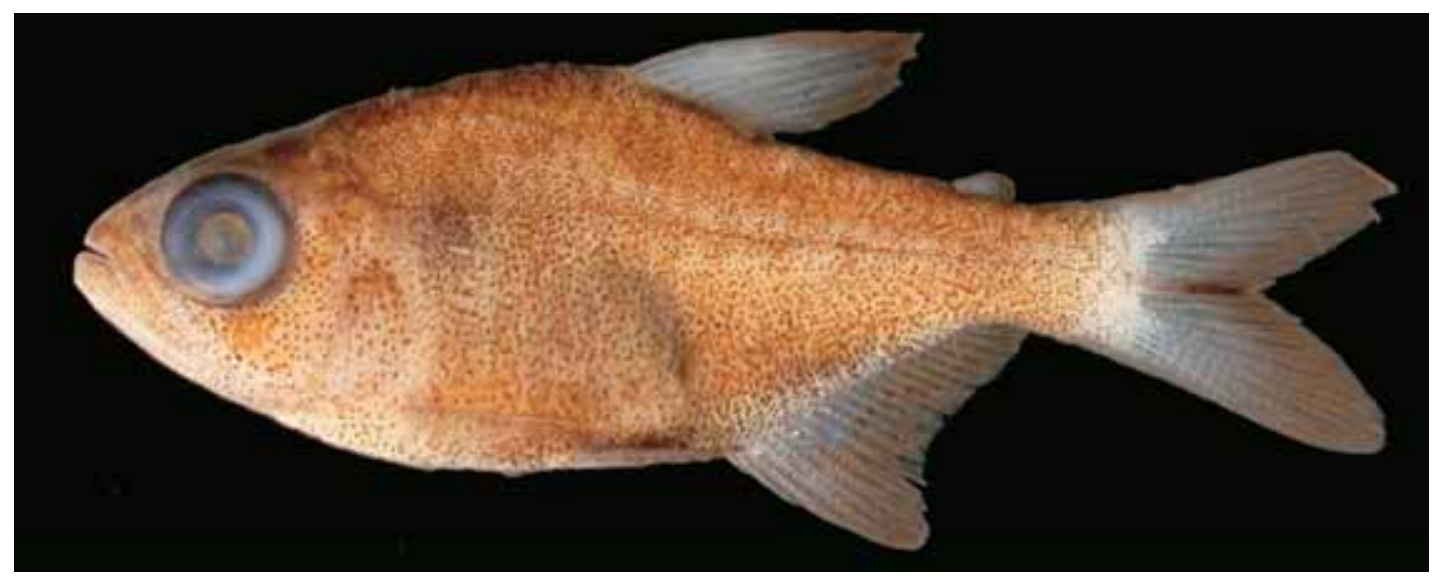

Fig. 6. Hyphessobrycon eilyos, holotype, MZUSP 75126, $22.3 \mathrm{~mm}$ SL, Brazil, Mato Grosso, município de Alto Araguaia, ribeirão do Sapo. 


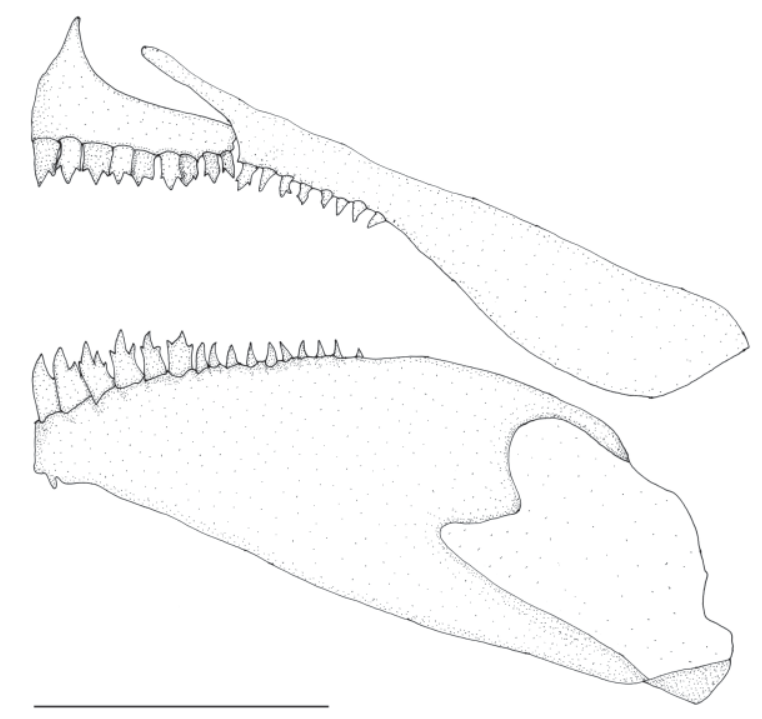

Fig. 7. Hyphessobrycon eilyos, paratype, MZUSP 41406. Upper and lower jaws, lateral view, left side. Scale bar $1 \mathrm{~mm}$.

Ecological notes. At the ribeirão do Sapo (Fig. 8), the type-locality, Hyphessobrycon eilyos was only collected in backwaters of the stream. These backwaters were characteristically tea-colored, contrasting with the clear water of the mainstream, and were choked with vegetable debris from the adjacent riparian forest. Our limited collecting activity at the Córrego do Rancho did not allow us to ascertain what microhabitat was occupied by Hyphessobrycon eilyos, but presumably the species is associated with large flooded areas with abundant aquatic vegetation present in that stream. For remarks on its syntopy with $H$. langeanii and $H$. weitzmanorum, see "Ecological notes" under $H$. langeanii.

Etymology. From the Greek eilyos, den, lurking-place, in allusion to the habitat (backwaters choked with vegetal matter) occupied by the new species (and according to local information, shared with anacondas, Eunectes murinus). A noun in apposition.

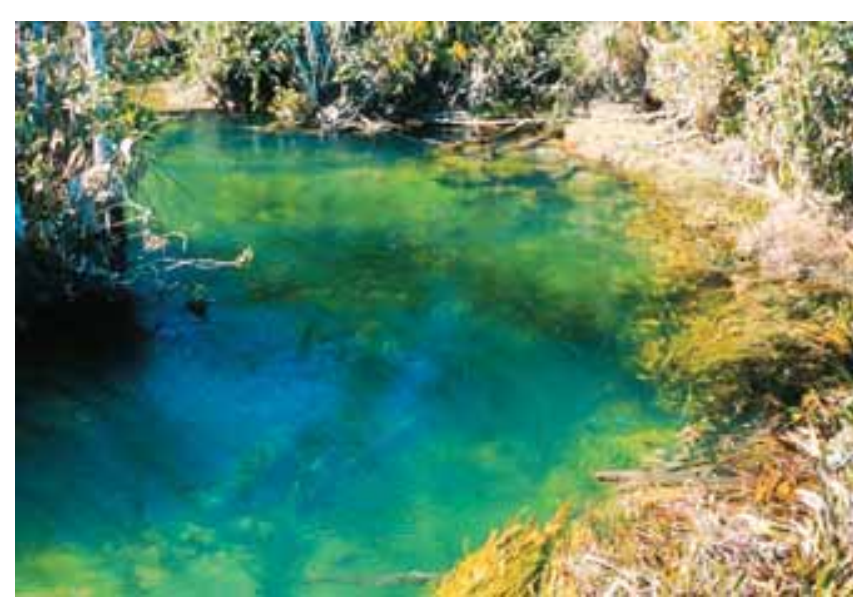

Fig. 8. Type locality of Hyphessobrycon eilyos, ribeirão do Sapo, Mato Grosso, município de Alto Araguaia, Brazil.
Table 2. Morphometric data for Hyphessobrycon eilyos. Measurements based on the holotype (MZUSP 75126) and 61 paratypes (MZUSP 41406, 56 ex.; MZUSP 73344, 4 ex.; MZUSP 73363, 1 ex.).

\begin{tabular}{lllll}
\hline & \multicolumn{2}{l}{ holotype $\mathrm{n}$} & range & mean \\
\hline Standard length (mm) & 22.3 & 62 & $15.8-24.7$ & - \\
$\begin{array}{l}\text { Percents of standard length } \\
\text { Depth at dorsal-fin origin }\end{array}$ & 40.0 & 62 & $32.0-40.7$ & 37.2 \\
Snout to dorsal fin origin & 54.1 & 62 & $50.6-58.5$ & 53.6 \\
Snout to pectoral-fin origin & 33.8 & 62 & $30.5-36.6$ & 33.0 \\
Snout to pelvic-fin origin & 51.4 & 62 & $47.4-55.9$ & 50.2 \\
Snout to anal-fin origin & 64.8 & 62 & $61.9-69.0$ & 64.7 \\
Caudal peduncle depth & 12.2 & 62 & $9.2-13.0$ & 11.3 \\
Caudal peduncle length & 12.6 & 62 & $11.7-17.4$ & 15.1 \\
Pectoral-fin length & 21.0 & 62 & $14.0-22.6$ & 20.1 \\
Pelvic-fin length & 18.3 & 62 & $14.1-20.0$ & 17.3 \\
Dorsal-fin base length & 14.7 & 62 & $12.4-16.4$ & 14.3 \\
Dorsal fin height & 28.7 & 62 & $23.7-31.5$ & 28.4 \\
Anal-fin base length & 27.5 & 62 & $23.1-29.3$ & 25.8 \\
Anal-fin lobe length & 19.5 & 62 & $14.2-22.5$ & 19.6 \\
Eye to dorsal-fin origin & 36.4 & 62 & $32.7-38.9$ & 35.8 \\
Dorsal-fin origin to caudal-fin & 51.9 & 62 & $47.8-55.5$ & 52.4 \\
base & & & & \\
Bony head length & 34.3 & 62 & $30.4-37.6$ & 32.8 \\
Percents of head length & & & & \\
Horizontal eye diameter & 35.4 & 62 & $35.2-44.4$ & 39.9 \\
Snout length & 19.7 & 62 & $19.7-27.2$ & 22.7 \\
Least interorbital width & 26.8 & 62 & $23.3-33.6$ & 27.7 \\
Upper jaw length & 45.2 & 62 & $33.9-51.3$ & 46.7 \\
\hline
\end{tabular}

\section{Hyphessobrycon weitzmanorum, new species} Figs. 9-10

Holotype. MZUSP 73315 (male, 22.1 mm SL): Brazil, Mato Grosso, município de Alto Araguaia, córrego Mosquito, km 476.3 of Ferronorte railroad, $17^{\circ} 25^{\prime} 8^{\prime \prime} \mathrm{S}, 5^{\circ} 13^{\prime} 60^{\prime \prime} \mathrm{W}$; C.R. Moreira \& F.C.T. Lima, 19 May 2001.

Paratypes. All localities in Brazil, Mato Grosso, município de Alto Araguaia: MZUSP 73314 (93, 5 cs, 13.9-25.5 mm SL); MCZ 162372 (5, 18.2-22.6 mm SL); USNM 371924 (5, 19.7-20.7 $\mathrm{mm}$ SL), same data as holotype. MZUSP 73317 (26, 12.6-20.0 $\mathrm{mm} \mathrm{SL}$ ), córrego do Sapinho, km 474.64 of Ferronorte railroad, 17²5'55'S, 5314'34'W; C.R. Moreira \& F.C.T. Lima, 19 May 2001. MZUSP 73342 (25, 12.6-21.4 mm SL), ribeirão de Sapo, km 464.04 of Ferronorte railroad, 17³1'11'’S, 5315'33’'W; C.R. Moreira \& F.C.T. Lima, 21 May 2001. MZUSP 73271 (20, 12.9$22.1 \mathrm{~mm}$ SL), córrego Boiadeiro, km 487.08 of Ferronorte railroad, 17²0' 1'S, 5314'53'”W; C.R. Moreira \& F.C.T. Lima, 16 May 2001. MZUSP 73254 (49, 10.3-22.3 mm SL); MNRJ 24782 (5, 18.3-19.7 mm SL), córrego Gordura, km 491.4 of Ferronorte railroad, $17^{\circ} 18^{\prime} 20^{\prime}$ 'S, 5316'22'W; C.R. Moreira \& F.C.T. Lima, 15 May 2001. 
Diagnosis. Hyphessobrycon weitzmanorum is distinguished from all congeners, except $H$. tortuguerae Böhlke, $H$. bifasciatus Ellis, H. savagei Bussing, H. flammeus Myers, H. griemi Hoedeman, $H$. balbus Myers, $H$. itaparicensis Lima \& Costa, and $H$. columbianus Zarske \& Géry, by possessing two humeral spots. Hyphessobrycon weitzmanorum is distinguished from $H$. bifasciatus, $H$. savagei, $H$. flammeus, $H$. tortuguerae, $H$. griemi, $H$. itaparicensis, and $H$. columbianus by possessing a general dark color pattern, due to a high concentration of dark chromatophores uniformly distributed over the lateral surfaces of the body (vs. a general clear color pattern, with few, scattered chromatophores over the lateral surfaces of the body). Additionally, Hyphessobrycon weitzmanorum differs from $H$. bifasciatus, $H$. griemi, and $H$. tortuguerae by possessing two intensely pigmented, vertically-elongate humeral spots (vs. second humeral blotch fainter in $H$. bifasciatus; first humeral blotch fainter in H. griemi; and both humeral blotches small, not vertically-elongate in $H$. tortuguerae). Hyphessobrycon weitzmanorum is distinguished from $H$. flammeus and $H$. savagei by possessing wide humeral blotches, with somewhat rounded margins (vs. humeral blotches narrow, with straight margins). Hyphessobrycon weitzmanorum is distinguished from $H$. balbus in possessing 5-9 perforated lateral line scales (vs. 11-22) and in having the second humeral blotch intensely pigmented (vs. very faint). Hyphessobrycon weitzmanorum is distinguished from $H$. itaparicensis Lima \& Costa (2001) by possessing a lower number of branched anal-fin rays (17-21, vs. 22-25) and lack of a midlateral, horizontal stripe, crimson in life, that extends from the vertical just posterior of the dorsalfin origin to the caudal peduncle. Hyphessobrycon weitzmanorum is distinguished from $H$. columbianus Zarske \& Géry (2002), by possessing a lower number of branched anal-fin rays (17-21, vs. 23-24) and orange pigmentation in life on the caudal, anal, dorsal and pelvic fins (vs. red pigmentation on caudal, and anal).

Description. Morphometric data of the holotype and paratypes are presented in Table 3. Body compressed,

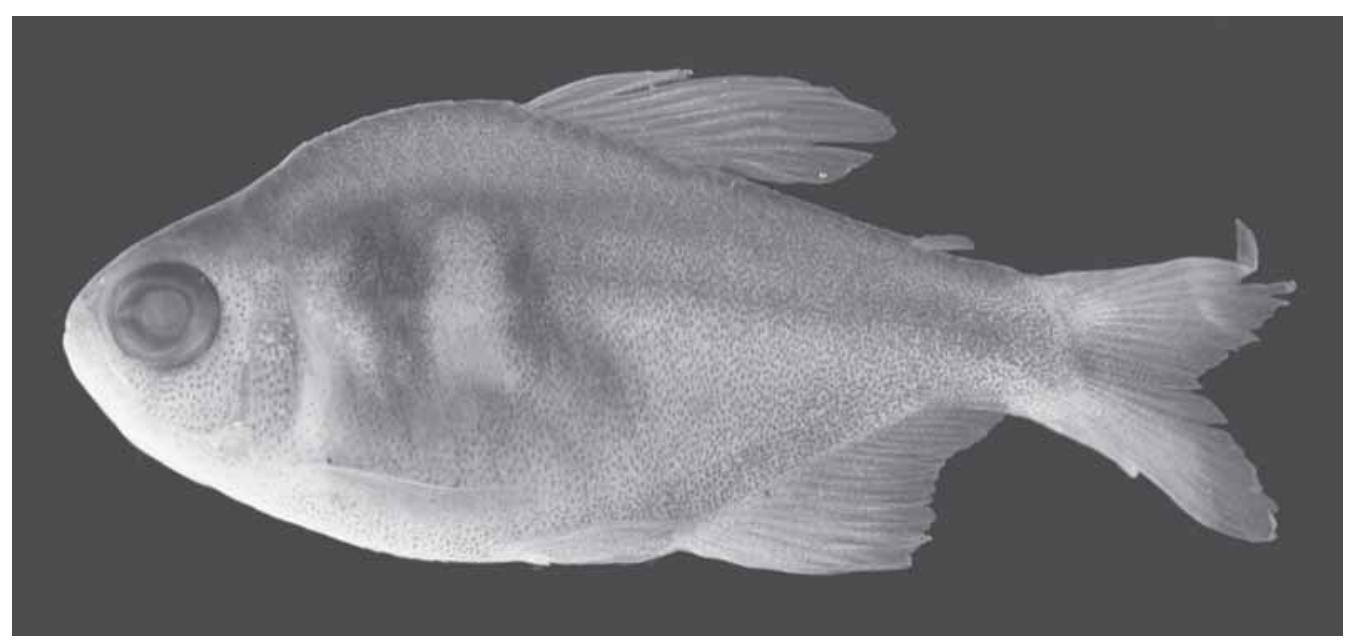

Fig. 9. Hyphessobrycon weitzmanorum, holotype, MZUSP 73315, $22.1 \mathrm{~mm}$ SL, Brazil, Mato Grosso, município de Alto Araguaia, córrego Mosquito.

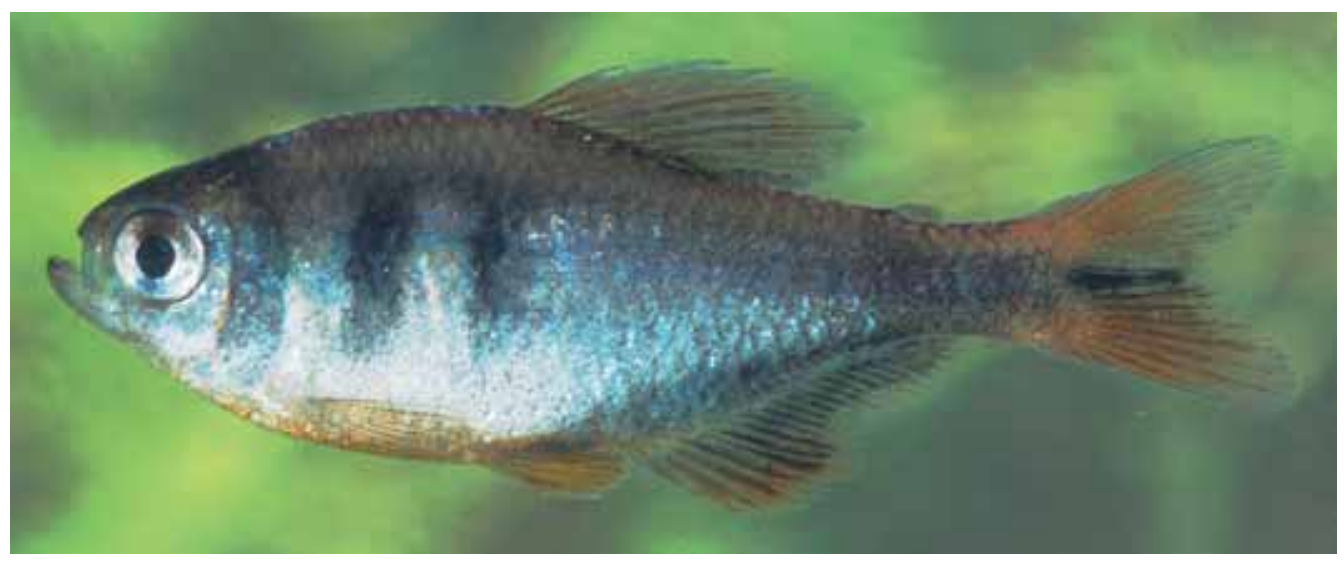

Fig. 10. Paratype of Hyphessobrycon weitzmanorum, MZUSP 73314, 21.5 mm SL, Brazil, Mato Grosso, município de Alto Araguaia, córrego Mosquito. Photographed in life. 
moderately deep, greatest body depth at vertical through middle of distance between pectoral- and pelvic-fin insertions. Dorsal profile of head convex from upper lip to vertical through middle of orbit; slightly concave from latter point to tip of supraoccipital spine. Predorsal profile of body convex, dorsalfin base straight to slightly convex, posteroventrally inclined. Body profile straight to convex from end of dorsal-fin base to adipose fin; slightly concave to slightly convex between latter point to origin of dorsalmost procurrent caudal-fin ray. Ventral profile of head and body convex from lower lip to anal-fin origin. Body profile along anal-fin base straight to slightly convex and posterodorsally inclined. Ventral profile of caudal peduncle slightly concave to slightly convex.

Jaws equal, mouth terminal. Maxilla reaching posteriorly to first third of the orbit. Premaxillary teeth in two rows (Fig. 11). Outer row with 2(4) unicuspid teeth. Inner row with 5(1) or 6(3) uni- to tricuspid teeth. Maxilla with 3(1), 4(2), 5(1), or 6(1), unito tricuspid teeth. Dentary with $4(4)$ or 5(1) large tri- to tetracuspid teeth followed by 7 to 11 smaller unicuspid teeth.

Scales cycloid, with few radii. Lateral line incompletely pored, with 5(5), 6(12), 7(15), 8(4), or 9(2) perforated scales. Lateral series scales including perforated scales 31(12), 32(10), 33*(11), 34(4), or 35(1). Horizontal scale rows between dorsal-fin origin and lateral line 6(17) or 7(23), not including scale of predorsal series situated just anterior to first dorsal-fin ray. Horizontal scale rows between lateral line and pelvic-fin origin 4(2), 5(34), and 6(3). Predorsal scales 9*(10), 10(20), 11(2), or 13(1). Circumpeduncular scales 12(1), 13(17), 14*(9), or 15(1). Single row of 4-6 scales cover base of anteriormost anal-fin rays.

Dorsal-fin rays iii, $8 *(32)$, iv,8(1), ii,9(16), iii,9(2), or ii,10(1). Dorsal-fin origin slightly anterior to middle of the standard length. First dorsal-fin pterygiophore inserting behind neural spine of 8 th(4), or 9th(1) vertebra. Adipose fin present. Unbranched anal-fin rays iii*(45), or iv(12). Branched anal-fin rays $17(9), 18^{*}(25), 19(17), 20(5)$, or $21(1)$. Anal-fin origin approximately at vertical through antepenultimate dorsal-fin rays. First anal-fin pterygiophore inserting behind hemal spine of 14th(3), or 15th(2) vertebra. Pectoral-fin rays i,8(3), 9(28), $10 *(27)$, or 11(1). Tip of pectoral fin reaching vertical through, or slightly beyond, pelvic-fin insertion. Pelvic-fin rays i,6*(59). Tip of pelvic fin usually reaching vertical through, or slightly beyond, anal-fin origin, but falling short of anal-fin origin in some specimens. Caudal fin forked, upper and lower lobes rounded, and similar in size. Principal caudal-fin rays 10+9(5). Ten(4), or 11(1) dorsal procurrent caudal-fin rays, and 8(1), $9(2)$ or 10(1) ventral procurrent caudal-fin rays. First gill arch with 7(5) epibranchial, 8(1), 9(3), or 10(1) ceratobranchial, 1(5) on cartilage between ceratobranchial and epibranchial, and 2(5) hypobranchial gill-rakers. Four(5) branchiostegal rays, $3(5)$ on anterior ceratohyal, and 1(5) on posterior ceratohyal. Vertebrae 32(4), or 33(1). Supraneurals 4(3), or 5(1).

Sexual dimorphism. One cleared and stained mature male (MZUSP 73314), with small hooks on unbranched, and 4 anteriormost branched pelvic-fin rays. One hook per segment usually present on distal two-thirds of rays. Anal fin with small hooks on last unbranched, and six anterior most branched rays. Usually, two paired hooks per segment on distal one-half of rays. In whole specimens, the heavy concentration of dark chromatophores makes examination of the hooks difficult.

Color in alcohol. Ground color cream. Guanine present on opercle and infraorbitals. Dark chromatophores densely concentrated on dorsal surface of head and anterior surface of lower jaw. Small dark chromatophores present on maxilla, ventral margin of orbit, and first and second infraorbitals; remaining infraorbitals and opercle with larger and more scattered dark chromatophores. Ventral portion of head with very small, scattered, dark chromatophores. Dorsal midline of body with dense concentration of dark chromatophores. Lateral surfaces of body densely covered with dark chromatophores, less concentrated on anterior portion of abdominal cavity. Two vertically-elongate black humeral spots. Anterior humeral spot well-defined, roughly rectangular, with dark chromatophores more concentrated on its approximately dorsal one-half. Second humeral spot less defined, variously shaped, with border ranging from roughly rectangular to more or less circular. Faint dark, relatively wide, midlateral stripe, extending from second humeral spot to rear of caudal peduncle. Some specimens with faint dark stripe running along anal-fin base. Densely concentrated dark chromatophores present on fins, most prominently on dorsal and anal fins. Caudal fin with middle rays more darkly pigmented than remainder of fin.

Color in life. Based on four photographed exs (MZUSP 73314, 2 exs, 21.5-23.4 mm SL; MZUSP 73254, 1 ex, 20.7 mm SL; MZUSP 73271, 1 ex, 22.7 mm SL; Fig. 10). Dorsolateral portion of body and caudal peduncle gray to dark gray. Sides of head silvery. Ventrolateral portion of body, except on caudal

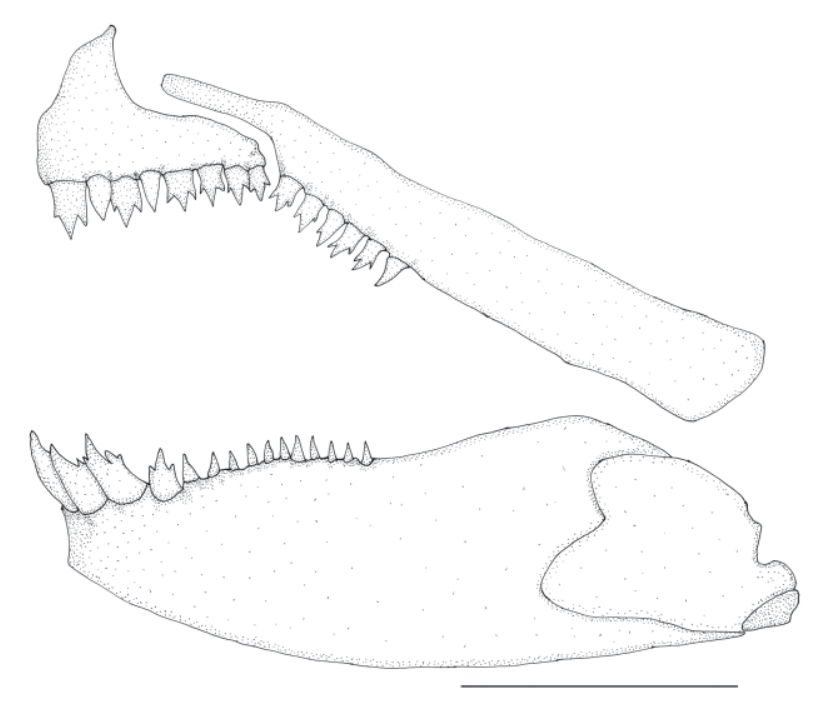

Fig. 11. Paratype of Hyphessobrycon weitzmanorum, MZUSP 73314. Upper and lower jaws, lateral view, left side. Scale bar $1 \mathrm{~mm}$. 
Table 3. Morphometric data for Hyphessobrycon weitzmanorum. Measurements based on the holotype (MZUSP 73315) and 53 paratypes (MZUSP 73254, 9 ex.; MZUSP 73271, 5 ex.; MZUSP 73314, 29 ex.; MZUSP 73317, 5 ex.; MZUSP 73342, 5 ex.).

\begin{tabular}{|c|c|c|c|c|}
\hline \multirow[b]{2}{*}{ Standard length (mm) } & \multicolumn{2}{|c|}{ holotype $\mathrm{n}$} & \multirow{2}{*}{$\begin{array}{l}\text { range } \\
17.2-25.5\end{array}$} & \multirow{2}{*}{$\begin{array}{l}\text { mean } \\
-\end{array}$} \\
\hline & 22.1 & 54 & & \\
\hline \multicolumn{5}{|l|}{ Percents of standard length } \\
\hline Depth at dorsal-fin origin & 45.5 & 54 & $36.5-46.5$ & 41.3 \\
\hline Snout to dorsal fin origin & 49.2 & 54 & $47.3-53.3$ & 50.3 \\
\hline Snout to pectoral-fin origin & 28.4 & 54 & $25.6-29.3$ & 27.5 \\
\hline Snout to pelvic-fin origin & 50.0 & 54 & $44.5-51.0$ & 48.0 \\
\hline Snout to anal-fin origin & 64.8 & 54 & $58.6-67.0$ & 62.7 \\
\hline Caudal peduncle depth & 14.7 & 54 & $10.3-15.0$ & 12.9 \\
\hline Caudal peduncle length & 15.1 & 54 & $10.7-16.2$ & 13.3 \\
\hline Pectoral-fin length & 24.9 & 54 & $20.4-26.5$ & 23.8 \\
\hline Pelvic-fin length & 19.0 & 54 & $15.5-21.6$ & 18.5 \\
\hline Dorsal-fin base length & 18.5 & 54 & $14.5-19.1$ & 17.3 \\
\hline Dorsal-fin height & 37.5 & 54 & $30.2-43.2$ & 36.7 \\
\hline Anal-fin base length & 29.9 & 54 & $27.3-34.1$ & 30.6 \\
\hline Anal-fin lobe length & 23.9 & 54 & $17.9-25.3$ & 21.4 \\
\hline Eye to dorsal-fin origin & 36.8 & 54 & $33.7-39.5$ & 36.8 \\
\hline $\begin{array}{l}\text { Dorsal-fin origin to caudal-fin } \\
\text { base }\end{array}$ & 59.3 & 54 & $50.6-60.9$ & 56.4 \\
\hline Bony head length & 27.1 & 54 & $25.3-29.2$ & 27.2 \\
\hline \multicolumn{5}{|l|}{ Percents of head length } \\
\hline Horizontal eye diameter & 40.2 & 54 & $35.2-51.1$ & 41.5 \\
\hline Snout length & 21.9 & 54 & $15.9-24.7$ & 20.6 \\
\hline Least interorbital width & 34.4 & 54 & $26.9-37.2$ & 32.0 \\
\hline Upper jaw length & 46.4 & 54 & $39.0-54.4$ & 44.6 \\
\hline
\end{tabular}

peduncle, grayish pale, with bluish, bright silvery coloration. Deep gray stripe present on anal-fin base. Dorsal and ventral midlines bright orange. Orange pigmentation present on basal portion of dorsal and caudal fin, distal portion of anal-fin lobe, and pelvic fin. Black stripe extends along middle caudalfin rays.

Geographic distribution. Hyphessobrycon weitzmanorum is known from tributaries of the upper rio Araguaia basin in the state of Mato Grosso, Brazil (Fig. 5).

Ecological notes. Hyphessobrycon weitzmanorum was usually collected in relatively large, clearwater streams with abundant aquatic vegetation. The single exception was the type locality, córrego Mosquito, which was a first-order, relatively small stream running through a large wetland covered by tall grass. In all streams, $H$. weitzmanorum was observed in small groups of 2-5 individuals, that were sometimes apparently associated with Cnesterodon septentrionalis (Poeciliidae). Hyphessobrycon weitzmanorum was always associated with submerged vegetation. Córrego Gordura, where more detailed subaquatic observations of $H$. weitzmanorum were conducted, was a wide stream (6-10 m), with deep, sandybottomed pools (2-4 $\mathrm{m}$ ) alternating with shallow, vegetationcovered riffles $(0.30-1 \mathrm{~m})$. In this stream, $H$. weitzmanorum was often seen at sites along steep banks just below the riffles, with abundant vegetation and slow-flowing water. Individuals positioned in those locations undertook brief incursions into the fast-flowing water in higher portions of the water column, in order to pick drifting items in the current. Some North American cyprinids have also been reported to hover outside strong currents, darting into it to pick up drifting items (Matthews, 1998: 314, 414). For remarks on the syntopy of $H$. weitzmanorum with $H$. langeanii and $H$. eilyos, see "Ecological notes" above under H. langeanii.

Etymology. The specific name honors Stanley and Marilyn Weitzman, for their life-long interest and extensive contributions to the knowledge of Neotropical freshwater fishes. Including are several papers addressing the systematics of Hyphessobrycon and related genera.

\section{Discussion}

As constantly reiterated in the literature (e.g., Weitzman \& Fink, 1983, Weitzman \& Palmer, 1997), Hyphessobrycon is a systematic puzzle. Problems within the systematics of Hyphessobrycon range from the uncertainties regarding the alpha-taxonomy of most of its component species to the doubtful monophyly of the genus. In the absence of a hypothesis of the relationships among the members of Characidae, we follow the limits of the genus proposed by Eigenmann (1918).

Géry (1977: 467, 470), in his keys to the species of Hyphessobrycon, distinguished a group of species in the genus on the basis of the possession of a combination of a humeral and a caudal peduncle spot. In addition to the species cited by Géry (1977), the more recently described $H$. frankei Zarske \& Géry (1997) should be included in that assemblage given its possession of those features. Given the limited information available for most of these species, we relied primarily on literature information for the purpose of comparisons with $H$. langeanii. Species of this group, with the exception of $H$. reticulatus, $H$. hildae Fernández-Yépez, and H. melazonatus Durbin, either possess a faint, vertically-elongate humeral spot $[H$. santae (Eigenmann), H. anisitsi (Eigenmann), H. luetkenii (Boulenger), H. duragenys Ellis, $H$. frankei Zarske \& Géry; Eigenmann, 1918, 1921, Zarske \& Géry, 1997], faint and rounded humeral spot $[H$. robustulus (Cope), H. tenuis Géry, H. tropis Géry; Cope, 1870; Fowler, 1906; Géry, 1963, 1964], or an indistinct humeral spot [H. inconstans (Eigenmann \& Ogle), H. proteus Eigenmann, H. eos Durbin, and H. maculicauda Ahl; Eigenmann, 1913, 1918, 1921, Ahl, 1936]. Hyphessobrycon langeanii, in contrast, possesses an oval, well-defined humeral spot. Hyphessobrycon hildae and H. tenuis possesses a very small caudal peduncle spot (Fernández-Yépez, 1950; Géry, 1964), in contrast to the large, well-defined caudal peduncle spot of $H$. langeanii. Hyphessobrycon melazonatus can be distinguished from $H$. langeanii, as well from the remaining Hyphessobrycon species with a humeral and a caudal spots, by the possession 
of a conspicuous, narrow, dark stripe along the anal-fin base (Eigenmann, 1918). Hyphessobrycon reticulatus most resembles $H$. langeanii, sharing most color and meristic features. As indicated in the "Diagnosis" of $H$. langeanii, both species are distinguished by several characters. Regarding Hyphessobrycon maculicauda, is only known from the lost holotype (Zarske \& Géry, 1995), an aquarium specimen, bearing the vague type locality of "Mittelbrasilien". The lack of type specimen of H. maculicauda, in conjunction with the brief original description (Ahl, 1936) prevents a definitive comparison with $H$. langeanii. Nonetheless, $H$. maculicauda was described as possessing a small, faint humeral spot (vs. a well-defined, large humeral spot in $H$. langeanii), a large caudal peduncle spot, which extends vertically along the entire caudal peduncle (vs. large spot, restricted to the medial portion of the caudal peduncle), and 31 anal-fin rays (vs.18-23 anal-fin rays; counts including the first three, unbranched rays).

The overall dark color pattern formed by numerous dark chromatophores spread over the body observed in Hyphessobrycon eilyos is uncommon among congeners and other small characids. Lima \& Gerhard (2001) discussed the presence of dark color pattern in small characid fishes. In addition to the species mentioned by those authors, Hyphessobrycon balbus Myers (1927), and Hyphessobrycon weitzmanorum, also possess an overall dark color pattern formed by numerous dark chromatophores spread over the body. Among other characters, Hyphessobrycon eilyos can be diagnosed from Gymnocorymbus ternetzi, Hyphessobrycon megalopterus, $H$. balbus, and $H$. weitzmanorum by the absence of humeral spot. It can be distinguished from $H$. negodagua, H. parvellus, and Moenkhausia pittieri by the absence of dark chromatophores in the caudal-fin base, whereas these species possess a concentration of dark chromatophores on the caudal-fin base, although not forming a dark spot. The clear portion of the caudal fin in Hyphessobrycon eilyos corresponds to an area of carmine-red in living specimens. Also carmine-red is present in the dorsal and adipose fins. In contrast, Hyphessobrycon negodagua and Moenkhausia pittieri do not possess any red pigment in the caudal, dorsal or adipose fins. Hyphessobrycon parvellus possess a reddish pigmentation in the caudal fin (Lima \& Gerhard, 2001: 111). This pigmentation, however, is not as intense as observed in Hyphessobrycon eilyos, and it is absent from the dorsal and adipose fins. Moenkhausia pittieri is a typical Moenkhausia, hence differing from Hyphessobrycon eilyos in possessing a complete lateral line and scales over the caudal-fin base.

At this point, it is appropriate to make some remarks on the type-locality of Hyphessobrycon griemi, because its incorrectness may bring some doubt about the identity of the species, as well as the validity of $H$. weitzmanorum. In the original description, Hoedeman (1957) stated the type locality as being "Gojas, Brasilien". The Brazilian state of Goiás borders the Mato Grosso State, the borderline being the rio Araguaia. Given that, it would seem possible that the name
Hyphessobrycon griemi is being misapplied to a species from eastern Brazil, and that $H$. griemi would be rather a species from central Brazil, maybe the species herein described as $H$. weitzmanorum. We have not examined the holotype of Hyphessobrycon griemi, but the photograph in the original description (Hoedeman, 1957: fig. 2) clearly shows the diagnostic character generally attributed to that species, the second humeral blotch much more conspicuous than the first one, which is distinct from the condition observed in $H$. weitzmanorum. Subsequent to the publication of the original description, Hoedeman stated that $H$. griemi “....was imported in 1956 by Aquarium Hamburg from southeastern Brazil" (Hoedeman, 1974:666). In the few other instances in which the distribution of $H$. griemi was referred in the literature (Géry, 1977: 463, and Weitzman et al., 1988:419-420), the area of occurrence of the species was mentioned as being "S.E. Brazil" or, more precisely, "small coastal streams between Santos in São Paulo State and Joinville in Santa Catarina State". A definitive argument is the fact that M. Weitzman (pers. comm.) compared the holotype of H. griemi with material from southeastern Brazil and concluded that they represent the same species.

The relationships of the three Hyphessobrycon species described are uncertain in light of the lack of a hypothesis of inter-relationships within, or indeed evidence for the monophyly of Hyphessobrycon. For that reason the discussions about tentative relationships of the new species can only be based on overall similarity rather than synapomorphies, and, thus, may not reflect phylogeny. Hyphessobrycon langeanii is similar to congeners occurring in rivers of eastern Brazil, e.g. Hyphessobrycon luetkeni and $H$. reticulatus. Hyphessobrycon eilyos is a highly distinctive species, and no obvious similarities exist with a group of congeners. Hyphessobrycon weitzmanorum resembles closely some of the Hyphessobrycon species with two humeral spots, in particular H. griemi.

The three new species described in this paper suggest that the upper rio Araguaia basin has a substantial endemic component in its ichthyofauna. Six other fish species are apparently endemic from that portion of the basin: Creagrutus molinus Vari \& Harold (2001) (Characidae), Apareiodon tigrinus Pavanelli \& Britski (2003) (Parodontidae), Aspidoras velites Britto et al. (2002) (Callichthyidae), an undescribed member of the Hypoptopomatinae (Loricariidae), Cnesterodon septentrionalis Rosa \& Costa (1993) (Poeciliidae), and Simpsonichthys cholopteryx Costa et al. (2003) (Rivulidae). According to A. Melo (pers. comm.) and local residents, the upper rio Araguaia, above the major fall Cachoeira Couto Magalhães, lacks almost all of the larger fishes found downstream. We propose that the upper rio Araguaia represents a previously unrecognized area of fish endemism. Introduction of fishes from the lower rio Araguaia, such as curimbas (Prochilodus sp.) and pacus (Myleinae), along with a dam, that is being planned for the rio Araguaia in the region of Cachoeira Couto de Magalhães, pose threats to the unique ichthyofauna of the upper rio Araguaia. 
Comparative material. Hyphessobrycon cf. anisitsi: MZUSP 17312, 16; MZUSP 47879, 3; MZUSP 18513, 4. H. balbus: MCZ 31570, paratypes, 2; ANSP 90319, 1. H. bifasciatus: MZUSP 49857, 61. H. flammeus: MZUSP 51020, 1. H. griemi: MZUSP 63133, 641, 2 cs. H. luetkenii: MZUSP 18982, 2; MZUSP 19024, 25. H. negodagua: MZUSP 54589, paratypes, 102, 8 cs. H. parvellus: MZUSP 59949, 2, 1 cs. H. reticulatus: MZUSP 35661, 234, 2 cs; MZUSP 17830, 6; MZUSP 19015, 23; MZUSP 41714, 6; MZUSP 42612, 4; MZUSP 18620, 4; MZUSP 51017, 2; MZUSP 49335, 3. H. tortuguerae: UMMZ 199597, 30 .

\section{Acknowledgments}

We are grateful to P. Buckup, F. Langeani, R. Vari, S. and M. Weitzman for reading and commenting upon the manuscript. Stanley and Marilyn Weitzman also provided important information on the type-locality of Hyphessobrycon griemi. M. Weitzman generously shared with us unpublished information on the types of $\mathrm{H}$. griemi. Ferronorte S/A and Tetraplan Consultoria e Planejamento made the fieldwork possible. Alex Melo (Laboratório de Ictiologia de Ribeirão Preto) provided additional information on fishes from the upper rio Araguaia. The first author is grateful to FMNH, ANSP, MCZ, and AMNH, which made funds available for research in those institutions. Karsten Hartel, and C. Kenaley (MCZ), M. Sabaj, J. Lundberg, and M. Littman (ANSP) provided assistance during visiting their institutions. Douglas Nelson, and W. Fink (UMMZ), P. Buckup and A. Aranda (MNRJ) loaned material used in this study. The authors were financially supported by the Fundação de Amparo à Pesquisa do Estado de São Paulo (FAPESP).

\section{Literature Cited}

Ahl, E.1936. Beschreibungen neuer Fische der Familie Characidae aus Südamerika. Zoologischer Anzeiger, 114 (1/2): 19-26.

Britto, M.R., F.C.T. Lima \& C.R. Moreira. 2002. Aspidoras velites, a new catfish from the upper Rio Araguaia basin, Brazil (Teleostei: Siluriformes: Callichthyidae). Proceedings of the Biological Society of Washington, 115(4): 727-736.

Cope, E.D. 1870. Contribution to the ichthyology of the Marañon. Proceeding of the American Philosophical Society, 11:559-570.

Costa, W.J.E.M., C.R. Moreira \& F.C.T. Lima. 2003. Simpsonichthys cholopteryx $\mathrm{n}$. sp. (Cyprinodontiformes: Rivulidae: Cynolebiatinae): a new dwarf annual fish from the upper Rio Araguaia basin, central Brazil. Aqua, Journal of Ichthyology and Aquatic Biology, 6(4): 139-144.

Eigenmann, C.H. 1913. Some results from an ichthyological reconnaissance of Colombia, South America. Part II. Indiana University Studies, 18: 1-32.

Eigenmann, C.H. 1918. The American Characidae [Part 2]. Memoirs of the Museum of Comparative Zoology, 43(2):
103-208, pls. 9-11, 13, 17-29, 33, 78-80, 93.

Eigenmann, C.H. 1921. The American Characidae [Part 3]. Memoirs of the Museum of Comparative Zoology, 43(3): 209-310, pls. 30-32, 40-55, 61-62, 64, 66, 69, 85, 87, 89, 92.

Fernández-Yépez, A. 1950. Algunos peces del río Autana. Novedades Científicas, ser. Zool. (2): 1-18, 3 pls.

Fink, W. L. \& S. H. Weitzman. 1974. The so-called cheirodontin fishes of Central America with description of two new species (Pisces, Characidae). Smithsonian Contributions to Zoology, 172: 1-46.

Fowler, H.W. 1906. Further knowledge of some heterognathous fishes. Part. 1.Proceedings of the Academy of Natural Sciences, Philadelphia, 58: 293-351.

Géry, J. 1963. Three new tetras from the upper Rio Negro near Tapurucuara. Tropical Fish Hobbyist, 12(3): 9, 11, 13, 1415, 57-59, 62-63.

Géry, J. 1964. Poissons characoides de l'Amazonie péruvienne. Beitrage zur Neotropischen Fauna, 4(1): 1-44.

Géry, J. 1977. Characoids of the World. T.F.H. Publications, Neptune City, NJ, 672 pp.

Hoedeman, J.J. 1957. Hyphessobrycon griemi, eine farbenprächtige Neuheit der Bifasciatus-Gruppe aus Gojas. Die Aquarien- und Terrarienzeitschrift (DATZ), 10(4): 87-89.

Hoedeman, J. J. 1974. Naturalists' Guide to Fresh-Water Aquarium Fish. Sterling Publ. Co., Inc, New York, 1152 pp.

Lima, F. C. T., L. R. Malabarba, P. A. Buckup, J. F. Pezzi da Silva, R. P. Vari, A. Harold, R. Benine, O. T. Oyakawa, C. S. Pavanelli, N. A. Menezes, C. A. S. Lucena, M. C. S. L. Malabarba, Z. M. S. Lucena, R. E. Reis, F. Langeani, L. Casatti, V. A. Bertaco, C. Moreira \& P. H. F. Lucinda. 2003. Genera Incertae Sedis in Characidae. Pp. 106-169 in: Reis, R. E., S. O. Kullander \& C. J. Ferraris (eds.), Check List of the Freshwater Fishes of South and Central America. Edipucrs, Porto Alegre, 729 pp.

Lima, F. C. T. \& P. Gerhard. 2001. A new Hyphessobrycon (Characiformes: Characidae) from Chapada Diamantina, Bahia, Brazil, with notes on its natural history. Ichthyological Exploration of Freshwaters, 12: 105-114.

Lima, S.M.Q. \& W.J.E.M. Costa. 2001. Hyphessobrycon itaparicensis (Characiformes: Characidae): a new tetragonopterine fish from a coastal island of northeastern Brazil. Cybium, 25(3): 233-237.

Matthews, W.J. 1998. Patterns in freshwater fish ecology. Chapman \& Hall, New York, NY, xxii + 756 pp.

Menezes, N. A. \& S. H. Weitzman. 1990. Two new species of Mimagoniates (Teleostei: Characidae: Glandulocaudinae), their phylogeny and biogeography and a key to the glandulocaudin fishes of Brazil and Paraguay. Proceedings of the Biological Society of Washington, 103: 380-426.

Myers, G.S. 1927. Description of new South American freshwater fishes collected by Dr. Carl Ternetz. Bulletin of the Museum of Comparative Zoology, 68: 107-135.

Pavanelli, C.S. \& H.A. Britski. 2003. Apareiodon Eigenmann, 1916 (Teleostei, Characiformes), from the TocantinsAraguaia Basin, with description of three new species. Copeia, 2003(2): 337-348. 
Rosa, R.S. \& W.J.E.M. Costa. 1993. Systematic revision of the genus Cnesterodon (Cyprinodontiformes: Poeciliidae) with the description of two new species from Brazil. Copeia, 1993(3): 696-708.

Taylor, W. R. \& G. C. Van Dyke. 1985. Revised procedures for staining and clearing small fishes and other vertebrates for bone and cartilage study. Cybium 9: 107-109.

Vari, R.P. \& A.S. Harold. 2001. Phylogenetic study of the Neotropical fish genera Creagrutus Günther and Piabina Reinhardt (Teleostei: Ostariophysi: Characiformes), with a revision of the Cis-Andean species. Smithsonian Contributions to Zoology, 613: 239 pp.

Weitzman, S. H. \& W. L. Fink. 1983. Relationships of the neon tetras, a group of South American freshwater fishes (Teleostei, Characidae), with comments on the phylogeny of New World characiforms. Bulletin of the Museum of Comparative Zoology, 150: 339-395.

Weitzman, S. H., N. A. Menezes \& M. J. Weitzman. 1988. Phylogenetic biogeography of the Glandulocaudini (Teleostei: Characiformes, Characidae) with comments on the distribution of other freshwater fishes in eastern and southeastern Brazil. Pp. 379-427 in: P. E. Vanzolini and W. R. Heyer (eds.), Neotropical distribution patterns: proceedings of a workshop. Academia Brasileira de Ciências, Rio de Janeiro, 488 pp.

Weitzman, S. H. \& L. Palmer. 1997. A new species of Hyphessobrycon (Teleostei: Characidae) from the Nebli- na region of Venezuela and Brazil, with comments on the putative 'rosy tetra clade'. Ichthyological Exploration of Freshwaters, 7: 209-242.

Zarske, A. \& J. Géry. 1995. Zur Status der von E. Ahl aufgestellten Salmler-Taxa (Teleostei: Characidae). Mitt. Zool. Mus. Berlim, 71: 103-120.

Zarske, A. \& J. Géry. 1997. Hyphessobrycon frankei n. sp. Beschreibung eines neuen Salmlers aus dem Einzugsgebiet des Río Ucayali in Peru (Teleostei: Characidae: Tetragonopterinae). Die Aquarien-und Terrarienzeitschrift (DATZ), 50(5): 308-312.

Zarske, A. \& J. Géry. 2002. Der Blaurote Kolumbien-Salmler. Hyphessobrycon columbianus n. sp., ein neuer Salmler (Teleostei, Characiformes, Characidae) aus dem kolumbianischen Darien. Das Aquarium, 391: 22-30.
Received April 30, 2003 Accepted August 7, 2003 